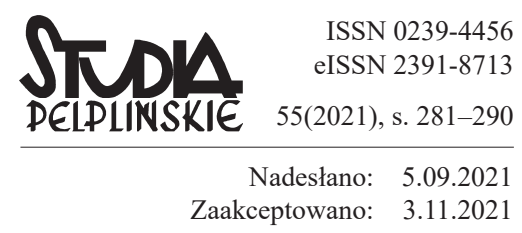

PIOTR PRUSKI

Uniwersytet Mikołaja Kopernika w Toruniu nouvele@poczta.onet.pl

ORCID: orcid.org/0000-0001-5703-5106

\title{
PERSONALISTYCZNE KRYTERIUM W REALIZACJI FUNKCJI GOSPODARCZEJ RODZINY W NAUCZANIU SPOŁECZNYM KOŚCIOŁA
}

DOI: http://dx.doi.org/10.12775/SPLP.2021.015

\begin{abstract}
Streszczenie
Artykuł stanowi analizę funkcji gospodarczej rodziny w aspekcie wydatkowania pozyskanych środków materialnych. Dobra doczesne, zgodnie z zasadami personalizmu stanowiącymi fundament nauczania społecznego Kościoła, winny służyć integralnemu rozwojowi człowieka. Absolutyzowanie bogactwa stanowi barierę w relacji do Boga. Sprzyja również generowaniu niesprawiedliwych dysproporcji, ograniczających podmiotowość jednostkową. Uczynienie z osoby nienaruszalnego principium społecznego, a także stosowanie zdrowego rozsądku, jest wpisane w porządek Boży, warunkujący wszystkie potrzeby jednostek i grup w ramach rodziny. Artykuł powstał w oparciu o wybrane teksty nauczania społecznego Kościoła.
\end{abstract}

Slowa kluczowe: osoba, rodzina, funkcja gospodarcza rodziny, zdrowy rozsqdek, integralny rozwój

THE PERSONALIST CRITERION IN THE ECONOMIC FUNCTION OF FAMILY AC-CORDING TO THE CATHOLIC SOCIAL TEACHING

\begin{abstract}
The paper offers an analysis of the economic function of the family, its income and expenditure. The material goods, according to the fundamental personalist social teaching of the Church, need to serve the integral growth of the human
\end{abstract}


being. Wealth, when idolised, creates an obstacle in our relationship with God. It may also cause unjust inequalities which hinder personal potential of some individuals. On the contrary, God's plan necessarily requires respect for every man as well as using the common sense. In such a way family can respond to individual and common needs of its members. This article is based on selected pieces of the Catholic Social Teaching.

Keywords: person, family, economic function of family, common sense, integral growth

Często mamy problemy z właściwym rozplanowaniem naszego budżetu domowego. Ciągle pracujemy, pieniądze szybko wpływają na nasze konto, a jeszcze szybciej z niego znikają. Większość z nas raczej mało kiedy dokładnie analizuje wydatki. Kiedy jednak przychodzi nam sprawdzić, ile pieniędzy wydajemy, często okazuje się, że wydajemy znacznie więcej niż myśleliśmy. Nie potrafimy oszczędzić na małe przyjemności czy na wymarzone wakacje. W końcu, jeśli mamy stały dochód, przecież moglibyśmy odkładać pewną kwotę pieniędzy miesięcznie na różnego rodzaju przyjemności lub chociażby na podróżowanie. Zapewne powyższe stwierdzenie wielu osobom może wydawać się niemożliwe, gdyż wychodzimy z założenia, że zarobione pieniądze rozsądnie wydajemy na bieżące potrzeby konsumpcyjne.

Pierwszym krokiem do oszczędzania jest prowadzenie budżetu domowego. Dlatego też podstawowym zadaniem, od jakiego rodziny powinny zacząć, jest systematyczne prowadzenie domowego budżetu. Aby to osiągnąć, należy prowadzić odpowiednią politykę w zakresie finansów. „Budżet domowy to zestawienie przychodów i rozchodów (w tym głównie wydatków) w ustalonym przedziale czasowym. Budżet domowy jest narzędziem efektywnie wspierającym zarządzanie finansami w gospodarstwie domowym"1. Rodzina, posiadając kapitał, którym umiejętnie będzie zarządzała, jest wstanie zaspokoić potrzeby poszczególnych swoich członków. Właśnie personalistyczne podejście do funkcji rodziny pozwala ujmować i rozwiązywać różnorodne zagadnienia i sprawy ludzkie zgodnie z tym założeniem: człowiek jest osobą - wartością niepowtarzalną i nieprzemijającą ${ }^{2}$. Zwrócenie uwagi na rodzinę, jej prawa i powinności, kierunek rozwoju i rolę oszczędzania pieniędzy jest zadaniem niezwykle pilnym. Wymaga ono wnikliwej analizy i konsekwentnego kontrolowania budżetu domowego. Wyzwanie to staje przed każdym członkiem rodziny, ale i przed wszystkimi pozostałymi, którzy rodzinę wspierają.

K. P. Łabenda, Budżet domowy pod kontrola, Warszawa 2011, s. 44.

2 Por. K. Wojtyła, Rozważania o istocie człowieka, Kraków 2000, s. 97. 


\section{PRZEZNACZENIE ŚRODKÓW FINANSOWYCH DO REALIZACJI INTEGRALNEJ WIZJI CZŁOWIEKA}

Głównym przeznaczeniem środków finansowych w gospodarstwie domowym jest konsumpcja, czyli kupowanie tego, co jest potrzebne do utrzymania się i normalnego życia członków rodziny. Pieniądze wydajemy na zaspokojenie w rodzinie pierwszorzędnych potrzeb: dachu nad głową, jedzenia, ubrania i zrobienie opłat. ,Jest świętym prawem natury, by ojciec rodziny troszczył się o utrzymanie i wszelkie potrzeby tych, których zrodził; i sama natura skłania go do tego, by dla dzieci, które odbijają w sobie i do pewnego stopnia przedłużają osobowość ojca, nabywał $i$ gromadził dobra potrzebne im do obrony przed niedolą podczas zmiennych kolei życia"’3. Bez tego wszystkiego nie da się godnie żyć, dlatego współczesny człowiek dąży do polepszenia warunków bytowania.

To dążenie do coraz lepszych i bardziej zadowalających warunków życia i coraz większej zamożności jest samo w sobie uzasadnione i potrzebne. Jednak, jak mówił św. Jan Paweł II, rodziny mogą czasami napotkać związane z tym dążeniem do szybszego rozwoju nowe niebezpieczeństwa i wypływające obowiązki, które prowadzą do nieumiarkowanego konsumpcjonizmu. „W sposobie powstawania i określania nowych potrzeb zawsze się wyraża mniej lub bardziej słuszna koncepcja człowieka i jego prawdziwego dobra. Poprzez decyzje dotyczące produkcji i konsumpcji ujawnia się określona kultura jako ogólna koncepcja życia. To właśnie tutaj powstaje zjawisko konsumpcjonizmu"4. Modlitwa, lektura słowa Bożego, chodzenie do Kościoła, rozmowa, to dobre praktyki dla budowania bliskiej relacji z Bogiem, bowiem w ten sposób buduje się relację małżeńską i rodzinną. ,W relacji wzajemnej komunii mężczyzna i kobieta realizują do głębi samych siebie, odnajdując się jako osoby poprzez szczery dar z siebie. Ich przymierze jedności przedstawione jest w Piśmie Świętym jako obraz Przymierza Boga z ludźmi i jednocześnie jako służba życiu"s. Para ludzka poprzez przymierze małżeńskie, uczestnicząc $\mathrm{w}$ dziele stwórczym świata (creatio continua) istotnie buduje bliską relację z Bogiem. Jeśli jednak małżonkowie za bardzo zwracają swe serce ku konsumpcjonizmowi, pieniądzom, to oddalają się od Boga niszcząc relacje z Nim i mogą też oddalić się od siebie niszcząc małżeńskie przymierze. Pieniądze w życiu każdego człowieka, choć nie mówi się o tym zbyt często, są bardzo ważne. Pozwalają na prowadzenie godnego życia, spełniania swoich marzeń i pozwalają na drobne przyjemności, takie jak wyjazdy czy zakupy. Określając nowe potrzeby oraz sposoby ich zaspokajania, koniecznie należy się kierować integralną wizją

Leon XIII, Rerum novarum, Wrocław 1995, 10.

4 Jan Paweł II, Centesimus annus, Watykan 1991, 36.

5 Papieska Rada Iustitia et Pax, Kompendium Nauki Społecznej Kościoła, Kielce 2005, 111. 
człowieka, która ogarnia wszystkie wymiary jego istnienia i która wymiary materialne i instynktowne podporządkowuje potrzebom wewnętrznym i duchowym.

W życiu społecznym należy uszanować każdego człowieka, ukazując pełne jego powołanie oraz dobro całego społeczeństwa. Człowiek bowiem jest bytem posiadającym swoje potrzeby, a zaspokajając je, nie powinien przy tym tracić godności osoby ludzkiej. Nie brak zatem powodów do niepokoju społecznego. „Wielu ludzi, zwłaszcza w krajach gospodarczo rozwiniętych, zdaje się do tego stopnia ulegać panowaniu ekonomii, że prawie całe ich życie osobiste i społeczne

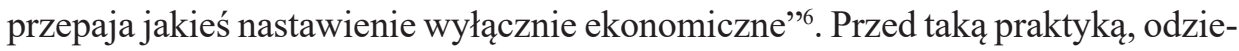
rającą człowieka z godności przestrzega nauczanie Katechizmu Kościoła Katolickiego „(...) wszelka praktyka, która sprowadza osoby jedynie do tego, by były zwykłymi środkami do osiągnięcia zysku, zniewala człowieka, prowadzi do bałwochwalczego stosunku do pieniądza (...)"ౌ. Kiedy finanse, mając potężną władzę, przeważają nad racjonalną polityką gospodarowania budżetem domowym, wtedy wkrada się nieład, przynoszący negatywne skutki społeczne. Jeżeli człowiek lub grupa zostają „,zniewoleni” przez gospodarkę, konsumpcyjny jej charakter i pieniądze, to trzeba ustalić kryteria, przesłanki i granice działania.

Temat pieniędzy dla wielu małżeństw jest tematem spornym. Głównie dzieje się tak wtedy, kiedy oboje małżonkowie przywiązują do tego dużą wagę i są na ten temat wyczuleni. W poradni dla małżeństw największe problemy finansowe zgłaszają zwykle ludzie ponadprzeciętnie zamożni czy wręcz bardzo bogaci. Zazwyczaj chodzi w tych wypadkach o podział środków na pieniądze żony oraz pieniądze męża i posądzanie współmałżonka o rozrzutność. Pieniądze służą do realizowania dobrych dzieł, do postępu ludzkości, ale kiedy stają się jedynym celem życia, niszczą człowieka i jego więzi ze światem zewnętrznym. Takie nauczanie, oparte na czytaniu liturgicznym z Ewangelii ${ }^{8}$, przedstawił papież Franciszek podczas Mszy św. odprawionej w poniedziałek 21 października 2013 roku w Domu św. Marty. Powiedział, że: „Gdy jakaś osoba jest przywiązana do pieniędzy, niszczy samą siebie, niszczy rodzinę" nizować pieniędzy. Pieniądze - uściślił papież Franciszek - służą do rozwijania dobrej działalności, licznych prac, mających za cel rozwój ludzkości. Tym, co należy natomiast potępić, jest ich niewłaściwe używanie. Odnośnie do tego papież powtórzył słowa wypowiedziane przez Jezusa w ewangelicznej przypowieści o bogaczu: „Kto skarby gromadzi dla siebie, nie jest bogaty u Boga”10. Jacek Pulikowski, nauczyciel akademicki, prowadzący między innymi poradnię dla

\footnotetext{
Sobór Watykański II, Gaudium et spes, Poznań 2002, 63.

KKK 2424.

Łk 12,13-21.

9 Franciszek, Pieniadze sa potrzebne, chciwość zabija (Watykan, 21.10.2013), „L'Osservatore Romano" wyd. pol. 12 (2013) s. 19.

10 Łk 12,13-21.
} 
małżeństw przeżywających kryzysy, mówiąc o poglądach na zarządzanie pieniędzmi w małżeństwie stwierdza, że świat zwariował na punkcie pieniędzy. Uczynił z nich cel życia. Żyjąc w tak zmaterializowanym świecie, w którym całe rzesze ludzi są uzależnione od chęci posiadania pieniędzy, trzeba koniecznie poznać stosunek do pieniędzy osoby, z którą zamierzamy spędzić całe życie ${ }^{11}$.

Stosunek do pieniędzy może być pozytywny lub negatywny, jednak to zawsze wypadkowa wielu czynników: wzorców z domu rodzinnego, ogólnego poczucia bezpieczeństwa, bieżącej sytuacji zawodowej i rodzinnej, wieku, stanu zdrowia itd. Już sama myśl, że może zabraknąć środków do życia, wywołuje u niektórych paniczny lęk, niepokój. Inni po prostu lubią mieć pieniądze na koncie, ponieważ podwyższa to ich samoocenę. Benedykt XVI mówi, iż: „Pokój w rodzinie wymaga zatem, z jednej strony otwarcia na transcendentne dziedzictwo wartości, a z drugiej nie bez znaczenia jest też zarówno roztropne zarządzanie dobrami materialnymi, jak układanie stosunków międzyosobowych. Gdy brak tego elementu, następuje stopniowa utrata wzajemnego zaufania z powodu niepewnych perspektyw, które stanowią zagrożenie dla rodziny" "2. Dopóki jesteśmy sami odpowiedzialni tylko za swój własny budżet, wszystko jest w porządku. Problem może pojawić się wtedy, gdy ta druga osoba ma zupełnie inny pomysł na zarządzanie domowymi finansami.

Sposób, w jaki zarządzamy finansami może budować lub burzyć małżeńską jedność: „Kto w drobnej rzeczy jest wierny, ten i w wielkiej będzie wierny, a kto w drobnej rzeczy jest nieuczciwy, ten i w wielkiej nieuczciwy będzie" ${ }^{13}$. Ten fragment pojawia się w perykopie ewangelii św. Łukasza zatytułowanej Dobry użytek z pieniądza. Jako drobne rzeczy Jezus uznaje pieniądze, wielką rzeczą jest relacja z Bogiem, ponieważ Jezus wyraźnie powiedział: „Nie możecie służyć Bogu i mamonie" wskazując, że po zasadach i wartościach, którymi kierujemy się w życiu, można rozpoznać, komu służymy. Ten, kto zarządza wspólnymi pieniędzmi w związku, często zaspokaja w ten sposób potrzebę posiadania władzy. Ważne, by zasady były jasne i akceptowane przez obie strony.

\section{ROZTROPNE ZARZĄDZANIE BUDŻETEM DOMOWYM}

Planowanie budżetu to spore wyzwanie dla wielu rodzin, które borykają się z problemami finansowymi. Kontrola i analiza wydatków, aby były prostsze $\mathrm{i}$ bardziej efektywne, mogą domagać się zewnętrznej pomocy. Warto skorzystać z oferowanych na rynku ekonomicznym różnego rodzaju pomocy: programów inter-

\footnotetext{
11 Zob. J. Pulikowski, Zakochanie... i co dalej?, Częstochowa 2011, s. 56.

12 Benedykt XVI, Orędzie na Światowy Dzień Pokoju (1 stycznia 2008), 9.

13 Łk 16, 10.
} 
netowych, instytucji zajmujących się prowadzeniem warsztatów z efektywnego zarządzania budżetem domowym, czy wiedza wielu ludzi, którzy chętnie dzielą się swoimi rozwiązaniami i doświadczeniami. Te przydatne narzędzia finansowe mogą być odpowiednią pomocą dla każdego, kto ceni czas, wygodę i przede wszystkim, swoje pieniądze.

Jedną z wielu instytucji działających na rynku, która pomaga zarządzać domowym budżetem jest Crown. Edukacja Finansowa Crown to działalność edukacyjna skierowana do każdego, prowadzona w oparciu o chrześcijańskie wartości, mająca na celu pomoc w zarządzaniu finansami. Edukacja Finansowa Crown w Polsce (taką przyjęto nazwę) zrodziła się z potrzeby zniwelowania rozdźwięku pomiędzy tym, co na temat finansów uważają ludzie, a tym, co na ten temat naucza Pismo Święte. Kilka osób z różnych środowisk chrześcijańskich niezależnie od siebie pragnęło, by Crown Financial Ministries mogło zaistnieć także w Polsce. Stało się to możliwe w styczniu 2008 roku. Ruch Nowego Życia (obecnie Ruch Chrześcijański Mt28) podpisując umowę o współpracy z Crown Financial Ministries stworzył dla Edukacji Finansowej Crown w Polsce prawne możliwości działania. Crown Financial Ministries jest platformą otwartą na współpracę ze wszystkimi, którzy chcą poznać, stosować i nauczać Bożych zasad zarządzania finansami. Instytucja obejmuje edukację w zakresie wychodzenia z długów, kształtowania nawyków w planowaniu wydatków i podejściu do budżetu rodzinnego, jak również do oszczędzania i wydawania pieniędzy. Crown prowadzi szkolenia w systemie wykładowym oraz warsztatowym.

Sposób gospodarowania finansami, który może pomóc małżonkom w zarządzaniu pieniędzmi, ale też zminimalizować ewentualne napięcia związane z wydawaniem pieniędzy to rozmowa, dialog małżeński. „We wzajemnych stosunkach członkowie wspólnoty rodzinnej są inspirowani i kierują się prawem bezinteresowności, które szanując i umacniając we wszystkich i w każdym godność osobistą jako jedyną rację wartości, przybiera postać serdecznego otwarcia się, spotkania i dialogu, bezinteresownej gotowości służenia, wielkodusznej służby i głębokiej solidarności"14. Komunikacja międzyosobowa, polegając zatem na wymianie informacji, odczuć, poglądów, tworzy porozumienie między osobami za pomocą słów i gestów, jakich używamy do wyrażenia tego, co chcemy przekazać drugiemu człowiekowi.

Pierwsze, co trzeba zrobić, to porozmawiać ze sobą na temat, dlaczego tak trudno jest się dogadać w sprawie pieniędzy? oraz: Co stoi na przeszkodzie, aby dojść do porozumienia? To właśnie dialog między małżonkami staje się okazją do wyrażenia swoich myśli, pragnień, ukazania swoich zainteresowań, na które trzeba wydać pieniądze. Każdy dialog zakłada zarówno element słuchania, jak i wyrażania siebie. Dzisiaj jednak, we współczesnym świecie mało siebie słuchamy

14 Jan Paweł II, Familiaris consortio, Warszawa 1983, 43. 
nawzajem. Główną przyczyną jest rytm, w jakim żyjemy. Ten pośpiech prowadzi do powierzchowności życia małżeńskiego i rodzinnego. Potrzeba pracy nad tym, żeby świadomie wygospodarować czas dla siebie ${ }^{15}$. Zapewne każdy chce zarządzać budżetem domowym w inny sposób. Nie można jednak oceniać, który pomysł jest lepszy.

Rozpoczynając pracę nad zarządzaniem budżetem domowym, każde z małżonków na kartce może wypisać główne założenia swojego planu wydatków np. na bieżący miesiąc, potem skonfrontować te założenia ze sobą. Posłużyć może temu karta pracy pt. Pieniądze i nasz budżet, zaproponowana przez Anthonego Garascie w książce pt. Zanim powiesz Tak. Na podstawie tego zestawienia można zobaczyć dysproporcje, które wynikają z różnicy w charakterach i sposobach postrzegania życiowych priorytetów. Oczywiście każdy ma prawo mieć inne priorytety, ale we wszystkim trzeba zachować zdrowy rozsądek. W tym zadaniu trzeba oceniać racjonalnie stan potrzeb gospodarstwa domowego i przyjemności, które mogą poczekać. Ważne jest również to, aby ustalić sposób przechowywania pieniędzy. Kto nimi będzie zarządzał itd. Prawdopodobnie, gdy tylko jeden z małżonków będzie chciał zarządzać pieniędzmi, to wynikną spory. Najlepiej robić to razem. Świetnym rozwiązaniem może okazać się założenie wspólnego konta bankowego z dwoma kartami do wypłat. Dzięki temu każdy będzie miał swój udział w planowaniu wydatków i unikniecie kłótni typu: Ty wydajesz pieniądze i przez to nie starcza na moje potrzeby. $\mathrm{Z}$ założeń, które zostały wypisane na kartkach można stworzyć plan, który będzie składał się z wspólnego i racjonalnego wykorzystania zdobytych środków pieniężnych, ale też kompromisów. Głównymi wydatkami powinny być zawsze te na utrzymanie rodziny, tj. zapłacenie czynszu, rachunków, wydatki na jedzenie i podstawowe produkty do domu, a unikanie postawy nadmiernego konsumpcjonizmu. Dążenie do niepohamowanej konsumpcji jest przejawem niewłaściwej hierarchii wartości. Jednocześnie ukazuje jakiś głęboki wewnętrzny deficyt człowieka. Jan Paweł II w encyklice Sollicitudo rei socialis pisze: „(...) wszyscy z bliska obserwujemy smutne skutki tego ślepego poddania się czystej konsumpcji: przede wszystkim jakiś rażący materializm, przy równoczesnym radykalnym nienasyceniu; jest bowiem rzeczą łatwo zrozumiałą, że jeśli się nie jest uodpornionym na wszechobecną reklamę i nieustannie kuszące propozycje nabycia nowych produktów, wówczas im więcej się posiada, tym więcej się pożąda, podczas gdy najgłębsze pragnienia pozostają niezaspokojone, a może nawet zagłuszone"16. Podsumowując, musimy zwrócić uwagę na to, że małżeństwa są różne, to co dla jednych będzie powodem konfliktu, dla innych będzie bez znaczenia, ważne jednak, aby oboje potrafili ocenić, czy ich sposób gospodarowania pieniędzmi łączy ich, czy dzieli.

15 M. Jarzębowski, Dialog podstawa matzeństwa, „Przewodnik Katolicki”, 21/2016, s. 42.

16 Jan Paweł II, Sollicitudo rei socialis, Watykan 1987, 28. 
Bóg przykazał człowiekowi, aby tak gospodarował pieniędzmi, żeby móc utrzymać swą rodzinę i prowadzić życie szczęśliwe ${ }^{17}$. „Powołanie mężczyzny do pracy pozostaje $\mathrm{w}$ koniecznym i nierozerwalnym związku $\mathrm{z}$ powołaniem do rodziny. Papież pisze: „Te dwa kręgi wartości - jeden związany z pracą, drugi wynikający z rodzinnego charakteru życia ludzkiego - muszą łączyć się z sobą prawidłowo i prawidłowo się przenikać"18. Każdy z małżonków powinien zatem posługiwać się podstawowymi zasadami rozsądnego zarządzania pieniędzmi zarówno w sposobie ich zdobywania, jak i wydawania.

Konkretnym przejawem tego będzie sumienne przykładanie się do powierzonej sobie pracy. Papież zauważa, że płaszczyzny odpowiedzialności moralnej dotyczące pracy ludzkiej mogą być wielorakie. „Z jednej strony praca pozostaje nieodłącznym elementem ludzkiej doczesności w aspekcie trudu, wysiłku i egzystencjalnego napięcia. Jest ona dla człowieka obowiązkiem, ale również drogą doskonalenia się, przejawem jego moralnej, indywidualnej odpowiedzialności jako podmiotu pracy; winna go cechować postawa sumienności, przejawiająca się nie tylko w podjęciu pracy, lecz także w odpowiednim jej wykonywaniu, zgodnie z odpowiadającym jej celem" "19. Rozsądne zarządzanie pieniędzmi, zarówno w sposobie ich zdobywania jak i wydawania, to przede wszystkim ułożenie budżetu uwzględniającego rzeczywiste potrzeby i wydatki rodziny, niemarnowanie pieniędzy na złe nawyki, hazard, alkohol, tytoń, nie kupowanie pod wpływem impulsu. Żeby ustrzec się przed takim działaniem, warto zwrócić uwagę na kilka przydatnych zasad: robić zakupy z listą, nauczyć się mówić dzieciom nie, robić zakupy, gdy jesteśmy najedzeni, zachować rozsądek, wyznaczyć określoną ilość czasu na zakupy, płacić gotówką.

Dziewięćset lat przed świętym Tomaszem napisał swój wykład o ewangelii św. Łukasza święty Ambroży. Przypowieść o nieuczciwym zarządcy powiązał on z przypowieścią o głupim bogaczu, dzięki czemu w bardzo prosty sposób wydobył z niej te dwie prawdy, że jesteśmy raczej zarządcami niż właścicielami dóbr materialnych oraz że powinniśmy się dzielić nimi z potrzebującymi. Nie można zapominać, że na ziemi człowiek jest tylko zarządcą, nie posiadaczem dóbr materialnych. To jedna z pierwszych i najważniejszych zasad, których członek rodziny musi się nauczyć. Wszystko, co człowiek posiada, stanowi dar od Boga. Bez danego czasu, przyznanych zdolności i Jego opatrzności człowiek nie miałby niczego. Wszystko należy do Boga. On daje po prostu wspaniały przywilej troszczenia się o Jego dobra. Skoro zaś finanse domowe zostały powierzone rodzinie jakby w zarząd, powinna ona starać się - zgodnie z wolą Stwórcy, Ostatecznego Właściciela tego, co posiadamy - tak nimi dysponować i tak ich używać, żeby nie

17 Zob. 1 Tm 5, 8 .

18 Jan Paweł II, Laborem exercens, Watykan 1981, 10.

19 Tamże 9. 
były przyczyną problemów i pozbawiania człowieka jego integralnej wizji, ale przyczyniały się do jego prawdziwego dobra i rozwoju.

\section{PODSUMOWANIE}

Jak mogliśmy zauważyć, wyszukiwanie najlepszych sposobów pomocy w zarządzaniu domowym budżetem jest zapewnienie małżonkom i całej rodzinie dobrej finansowej przyszłości i pozbawienie kłopotów związanych z niewłaściwym gospodarowaniem. Oczywiście, to co sprawdza się u jednej osoby, niekoniecznie musi zadziałać u drugiej. Prawo do korzystania przez wszystkich ludzi z dóbr stworzonego świata pochodzi od Boga. Jest ono bardziej fundamentalnym prawem niż prawo do własności prywatnej, które nie uchyla powszechnego przeznaczenia dóbr, dlatego że prawo własności już ze swej natury posiada charakter społeczny. Właściwe wydatkowanie pozyskiwanych przez rodzinę środków ma miejsce przy zastosowaniu zasad personalizmu. Kapitał bez względu na formę winien służyć integralnemu rozwojowi, na co zwracają uwagę papieże ostatnich dekad. Absolutyzacja środków materialnych z kolei generuje patologie społeczne wyrażające się w pogłębiających się niesprawiedliwych dysproporcjach, które wprost podważają podmiotowość jednostek. Pieniądze nie muszą być źródłem stresu w życiu człowieka, jeśli zacznie on gospodarować swoimi zasobami finansowymi w Boży sposób, to mogą stać się one źródłem błogosławieństw - zarówno dla niego samego, jak i dla innych ludzi. Jeśli za św. Augustynem rodzina postawi Boga i to co duchowe na pierwszym miejscu, to Pan Bóg pomoże gospodarować zasobami finansowymi. Jedną z najlepszych rzeczy, jakie możemy zrobić, jest nie zmarnować tych darów.

\section{Bibliografia}

Benedykt XVI, Orędzie na Światowy Dzień Pokoju, 1 stycznia 2008.

Franciszek, Pieniadze sa potrzebne, chciwość zabija (Watykan, 21.10.2013), „L'Osservatore Romano” wyd. pol. 12 (2013).

Jan Paweł II, Centesimus annus, Watykan 1991.

Jan Paweł II, Laborem exercens, Warszawa 1983.

Jan Paweł II, Sollicitudo rei socialis, Watykan 1987.

Jarzębowski M., Dialog podstawa matżeństwa, „Przewodnik Katolicki”, 2006. Katechizm Kościoła Katolickiego, Poznań 1992.

Leon XIII, Rerum novarum, Wrocław1995.

Łabenda K. P., Budżet domowy pod kontrola, Warszawa 2011. 
Papieska Rada Iustitia et Pax, Kompendium Nauki Społecznej Kościoła, Kielce 2005.

Pismo Święte, Biblia Tysiąclecia, Poznań 2002.

Pulikowski J., Zakochanie... i co dalej?, Częstochowa 2011.

Sobór Watykański II, Gaudium et spes, Poznań 2002.

Wojtyła K., Rozważania o istocie człowieka, Kraków 2000. 